\title{
Antigas leituras do Apocalipse na Igreja Grega
}

\author{
Ancient readings of the Revelation in \\ the Greek Church
}

Pedro Paulo Alves dos Santos

\section{Resumo}

Desejo expor o itinerário da leitura do Livro do Apocalipse através da produção de comentários desde a antiguidade tardia, nas Escolas do Oriente grego. Interessa mostrar também que existe uma rede de comunicação entre os diversos comentários, inteligência dos textos bíblicos, que explicita uma comunidade de leitura, estabelecendo elos entre autores, correntes teológicas, contextos sócio-eclesiais, em diversas épocas. Tudo isso, em vista da pertinência de uma obra literária que fascina e assusta leitores a dois mil anos de sua recepção no Cânon Bíblico, na liturgia e na cultura cristã.

Palavras-chave: História da Interpretação; Apocalipse de São João; Exegese Bíblica; Teorias Literárias.

\begin{abstract}
I wish to expose the itinerary of reading of the book of Revelation through the production of comments since late Antiquity, Greek Eastern schools. Care show also that there is a network of communication between the various comments, intelligence of the biblical texts, that spells a reading community, establishing links between authors, theological currents, socioecclesial contexts, at different times. All this, in view of the relevance of a
\end{abstract}


piece of literature that fascinates and scares readers two thousand years of its reception in the Biblical Canon, in the liturgy and in Christian culture.

\author{
Keywords: History of Interpretation; Revelation of St. John; Biblical \\ Exegesis; Literary Theories.
}

\title{
Introdução
}

O conceito de comunidade interpretativa seria entretanto o corretivo necessário para evitar uma 'apropriação ilegitima da parte de uma cultura, sem esquecer porém, que muitas vezes' uma interpretação legítima da Escritura pode partir de um grupo que, por razões dogmáticas, ou também político-culturais, que pode se encontar, inicialmente fora da legitima comunidade interpretante $e^{1}$.

Entre os estudiosos sobre o livro do Apocalipse, em língua portuguesa, percebe-se a carência de estudos suficientes sobre o itinerário histórico da exegese do desafiante Livro do Apocalipse ${ }^{2}$.

${ }^{1}$ GRECH, P. Introduzione. In: CONGREGAZIONE PER LA DOTTRINA DELLA FEDE. L'Interpretazione della Bibbia nella Chiesa. Roma: Vaticana, 2001, p. 11: "Il concetto di comunità interpretativa sarebbe tuttavia il correttivo necessario per evitare un'appropriazione illegitima da parte di una cultura, senza dimenticare però che spesso un'interpretazione legittima della Scrittura può partire da un gruppo che, per ragioni dogmatiche, ma anche politiche e culturali, si può trovare inizialmente al di fuori della legittima comunità interpretante". Sublinho a importância dos artigos de origem epistemológica e metodológica, que inserem a realidade da atividade exegética da(s) Igreja(s) no limiar de uma intensa discussão e aprofundamento dos resultados trazidos à tona, pela gama variada e complexa de metodologias literárias (não teológicas) "Le suddette considerazioni, insieme al progresso compituosi nele teorie ermeneutiche filosofiche, spingono anche a ripensare i metodi di interpretare la Sacra Scrittura. Ciò richiede evidentemente che la Scrittura sia letta dall"interno della Fede, ma anche arrichita dal dialogo com altre religioni, con le scienze profane (grifo é nosso!) e con i diversi svilupi culturali, che a loro volta porranno nuovi questioni al testo biblico", Il Messaggio Biblico e la sua Interpretazione. Bologna: Dehoniane, 2005, p.21. Do mesmo autor: 'The Regula Fidei' as Hermeneutical principle Yesterday and Today. In: CONGREGAZIONE PER LA DOTTRINA DELLA FEDE. L'Interpretazione della Bibbia nella Chiesa. Roma: Vaticana, 2001, pp. 208-231.

${ }^{2}$ DOS SANTOS, P P. A. Breve Percurso da Hermenêutica Bíblica". Atualidade Teológica (2008), pp. 29-41. Existe um estudo clássico, mas atual de SIMONETTI, M. Lettera o/e Allegoria. Um Contributo alla Storia delllesegesi Patristica. Roma: Patristicum, 1985, espec. pp. 289-306. Uma versão sintética desta questão: DOGLIO, C. "Duemila Anni di Tentativi. Storia dell'Interpretazione dell'Apocalisse". Parola e Vita 14/6 (2000), pp. 4-12. Um estudo sobre a recepção do Livro do Apocalipse no Primeiro Milênio cristã: MARUCCI, C. "La Canonicità dell'A pocalisse nel primo Millenio". In: COLACRAI, E. B. Percorsi nell'Apocalisse 
Afinal de contas, de que maneira, nestes dois milênios anteriores fixou-se uma tradição interpretativa desta obra estupenda? Que relevância tem para estudiosos, pastoralistas e curiosos deste livro a compreensão da recepção da mensagem do Apocalipse ao longo da história? Tudo isso, em vista da pertinência de uma obra literária que fascina e assusta leitores nos últimos dois mil anos de sua recepção no Cânon Bíblico, na liturgia e na cultura cristã .

Desde os primórdios compreendeu-se que o mesmo Espírito Santo ${ }^{4}$, que levou os autores do Novo Testamento a colocar por escrito a mensagem da Salvação (DV 7,18), traz igualmente à Igreja uma assistência contínua para a interpretação de seus Escritos Inspirados ${ }^{5}$. O assunto é complexo e interessante, pois inclui um campo mais vasto do aquele da Exegese. Enquanto razão e fé diante das Escrituras Sagradas, nele incluem-se também as múltiplas questões de contexto histórico e de linhas de desenvolvimento da Exegese Cristã ${ }^{6}$.

Por isso, em nossa exposição, impõe-se uma perspectiva cada vez mais interdisciplinar ${ }^{7}$. No tocante às novas relações com a literatura, em suas

di Giovani. Assisi: Cittadella, 2005, pp. 649-676.

3 O tema da renovação da leitura bíblica e a história da recepção de metodologias e 'approches', desde 1993, com o documento da Comissão Bíblica “A Interpretação da Bíblia na Igreja' tem produzido diversas ocasiões para a revisão das trajetórias das ciências bíblicas: “L'Interpretazione dela Bibbia nella Chiesa vent'anni dopo". Gregorianum 94/3 (2013).

${ }^{4}$ Discuti minha Tese Doutoral (Gregoriana, 1997) sob a orientação do Prof. Dr. Ugo Vanni sj, sobre o papel do Espírito na consciência teológica da Igreja. Sua realidade e de sua missão, seja no âmbito da Presença de Jesus de Nazaré, seja por suas implicações escatológicas. Consideramos também sua pré-compreensão como Horizonte da Igreja no Mundo (H. Muhlen, 1970). VANNI, U. “Tempo ed Eternità nell”Apocalissi: Traccia per uma Riflessioni Teológico Bíblica”. In: CASALEGNO, A. (org.). Tempo e Eternità. In Dialogo con Ugo Vanni S.I. Milano: San Paolo, 2002, pp. 25-72, espec. p.69, nota 60.

${ }_{5}$ PONTIFÍCIA COMISSÃO BÍBLICA. A Interpretação da Bíblia na Igreja, São Paulo: Paulinas, 1994, p. 116. O problema da inspiração e da verdade bíblicas (da Palavra Revelada): GABEL, H. "Inspiration und Wahreit der Schrift (DV11): neue Ansätze und Probleme im Kontext der gegenwärtigen winssenchaftlichen Diskussion”. In GRECH, P. Il Messaggio Biblico e la sua Interpretazione. Bologna: Dehoniane, 2005, pp. 64-89.

${ }^{6}$ THISELTON, A.C. New Horizons in Hermeneutics. Michigan: Zondervan, 1992; FORNBERG, HARRISVILLE \& SUNDBERG. The Bible in the Modern Culture. Theology and HistoricalCritical Method. Michigan: Grand Rapids, 1995; SÖDING, T. "Inmitten der theologie des Neuen Testaments: Zu den Voraussetzungen und Zielen neutestamentlicher Exegese". New Testament Studies (NTS) 42/2 (1996), pp. 161-184; LAMPE, P. "Wissenssoziologische Annähreungen an das Neue Testament". NTS 43/3 (1997), pp. 347-366; RIZZI, G. "Le Scritture tra i metodi storico-critici moderni e I principi ermeneutici fondamentali nel Giudaismo e nel Cristianesimo". RivBib. XLVI/2 (1998), pp. 121-223.

${ }^{7}$ AAVV. Comunicazione e ricezione: protagonisti, tecniche e vie del documento cristiano (IV -VI secolo), Roma, 2003. Ainda, L'esegesi dei Padri latini dalle origini a Gregorio Magno. 
diversas composições meta-teóricas contemporâneas, releva-se a oportunidade de inserir, de novo, a pesquisa exegética no conjunto das interrogações de outras ciências afins.

Inicialmente, indicar-se-ão os elementos mais característicos da exegese neotestamentária antiga grega ${ }^{8}$. Nosso escopo é aquele de analisar e individuar os "traços" da exegese do livro do Apocalipse, naquele momento do desenvolvimento da tradição da Igreja Grega.

A localização das coordenadas da produção dos Comentários e homilias permite-nos compreender o debate entre tradições 'oficiais' (doutrina e ortodoxia) e as 'marginais' (heresias) em relação à interpretação do livro do Apocalipse 9

Roma: Patristicum, 2000, 2vol. DOS SANTOS, P. P. "Ética e Justiça no Mundo do Cristianismo Primitivo. Um ensaio de Theologia Moral como Parenese Contemporânea". Communio 87 (2003), pp. 175-184. Refiro-me neste artigo aos esforços incorporados pela exegese bíblica do Novo Testamento ao aproximar-se dos resultados das pesquisas de várias ciências que removem os "selos" do mundo antigo e medieval. Tudo isto, para propor outras e mais precisas perspectivas acerca dos textos e contextos, em relação à análise de um texto religioso e antigo. Aplicado ao campo do Apocalipse Joanino, recomendo meu artigo: DOS SANTOS, P. P. "O Apocalipse de Jesus Cristo. Testemunho e Espírito da Profecia. A Tradição e a Eclesialidade joaninas como Fonte e Testemunho na busca de Traços do Cristianismo Primitivo". Atualidade Teológica 8 (2001), pp. 38-59; "Algumas Questões sobre as relações entre o âmbito do Cristianismo Primitivo e o surgimento de uma Consciência Histórico: História Social da Literatura Canônica como Parádosis". Atualidade Teológica 11 (2002), pp. 259-282.

8 SEVRIN, J.-M. The New Testament in Early Christianity: La récepction des écrits néotestamentaires dans le Christianisme primitf. Louvain: BETHEL 86, 1989. Uma empresa de grande valor como fonte para os estudos da exegese bíblica dos padres: A Bíblia Patristica (6 vols.), Paris: CNRS, 1975-1995. Muito tem se escrito, em particular, sobre a compreensão do Evangelho Joanino no período Patrístico, BAARDA, T. John 8:57B. The Contribution of Diatessaron of Tatian. NT, vol. XXXVIII, fasc. 4, (1996), pp. 336-343; BOISMARD, M.-E. Un'Évangile Pré-Johannique, Jean 2,13-4,54. vol.II, Tome II, Paris: J. Gabalda, 1994, uma recensão crítica: ELLIOTT, J.K. NT, vol. XXXVIII, fasc. 1, (1996), pp. 89-90; uma obra anterior de Boismard-Lamouille já havia sido criticada por F. NEIRYNCK, F Jean et les Synoptiques: Examen critique de l'exegése de M.-É. Boismard. BETHEL 44, 1979.

${ }^{9}$ BAUER, J.B. La exégesis del Nuevo Testamento y su trajectoria, in SCHREINER, J. (ed.). Introduccion a los Métodos de la Exégesis Bíblica. Barcelona: Herder, 1974, pp. 33-59; espec. p. 38: "La exégesis patristica se caracteriza por la actividad de dos escuelas exegéticas: por una parte está el didaskaleion de Orígenes en Alexandria, el cual difiende un triple sentido en la Escritura y busca de diferentes maneras las interpretaciones alegóricas y tipológicas." Tem sido intenso o esforço de muitos estudiosos em recuperar a teoria e a tradição exegética deixada por Orígenes: BASTIT-KALINOWSKA, A. L'Interprétation de l'évangile comme récit dans le Commentaire sur Matthieu d'Origène. In: La Narrativa Cristiana. Codici Narrativi, Strutture Formale, Schemi retorici. SEA 50 (1995), Roma, pp. 267-282. 


\section{As Características da Exegese Patrística}

Pois bem. Que Benefício se pode obter na prática do contato com a exegese patrística? Se pode pensar primeiro de todos os Padres gregos liam o Novo Testamento em sua língua materna e que, portanto, o tinham que entender melhor do que nós entendemos hoje. Mas isto só é verdade em parte porque a linguagem do novo testamento era a língua grega comum, chamada de koiné (...). Os Padres da Igreja já não estavam em contacto diretos com a língua do Novo Testamento, que lhe apresentava os mesmos enigmas que nos apresentam hoje.

Quais são os elementos que caracterizam primeiramente a exegese escriturística no período da fundação da tradição eclesial, chamada analogicamente ao ciclo dos Patriarcas? Como o ambiente latino da Patrística desenvolveu o filão oferecido pelo próprio processo da canonização neotestamentária? ${ }^{10}$

J. B. Bauer, buscando o carácter peculiar da exegese patrística, tanto grega como latina, afirma: "Caso contrario, a interpretação tipológica parece lutar com um problema que não é menos usual para nós do que para os Padres. O problema da precisão e do literalismo das Escrituras"

Por isso, a Interpretação dos Padres nos exorta a seguir as preocupações exegéticas mais modernas, a entender a história 'material' em sentido pneumático, dialético e existencial. Quais seriam os valores ou características perenes da exegese desse período ${ }^{11}$

\footnotetext{
${ }^{10}$ Em relação ao processo de canonização como testemunho do desenvolvimento da consciência da Igreja Antiga: BAUM, A.D. "Literatische Eichtheit als Kanonkriterium in der alten Kirche". ZNTW 88 (1997), pp. 97-110. Quando se fala de exegese dos Padres, em particular daqueles gregos, se deve pensar na dificuldade de saber a que textos eles se referem quando analisavam e atualizavam o sentido do Novo Testamento. Pergunta-se, imediatamente, tendo em conta a diferença de língua (grega) dos Padres e aquela do Novo Testamento, que dificuldades com a língua do NT eles encontraram diante de si em relação à língua corrente na Cristandade antiga, greco-romana, a língua dos padres e aquela do contexto mais amplo do período neotestamentário: O'CALLAGHAN, J. Affinità tra la koiné popolare e quella neotestamentária. In: LATOURELLE, R. (org.). Vaticano II, Bilancio \& Prospettive. Vinticinque anni dopo-19621987. Vol.1, Citadella, Assisi, 1987, pp. 193-203; GRECH, P. et Alii, (org.). L'Interpretazione della Bibbia nela Chiesa. Atti del Simposio promosso dalla Congregazione per la Dottrina della Fede, Roma, 1999.

${ }^{11}$ STUDEL, B. "L' Esegesi patristica. Un incontro con Cristo. Osservazioni sull'esegesi dei Padri Latini". Patristicum 40 (2000), Roma, pp. 321-344; GEYMONAT, M. "I Critici”. In: CAVAllo, G. Lo Spazio Letterario di Roma Antica. La recezione del testo. $2^{\text {a }}$ Ed. vol. III. Roma-Bari: Salerno, 1999, pp. 117-133; mais especificamente: PETRUCCI, A. "La Concezione cristiana del Libro fra il VI e VII secolo". CAVALLO, G. (ed). Libri e Lettori nel Medioevo. Guida Storica e Critica. 5a Ed. Bari: Laterza, 2003, p. 3-26.
} 
J. Bauer assim como outros autores está de acordo que ao menos quatro elementos são indispensáveis para tal caracterização:

a) Aos padres, como já aludimos acima, refere-se o processo de fixação do Cânon: "esse proceso intelectual de delimitar los escritos biblicos que podiam considerarse testimonio normativo de la predicacion de Cristo, separándolos de todos los escritos apócrifos y gnósticos." ${ }^{12}$

b) como critério para a seleção dos escritos que deveriam ser reconhe-

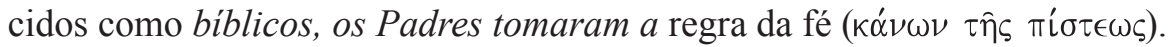

O Cânon neotestamentário tem um duplo valor conforme os dois sentidos

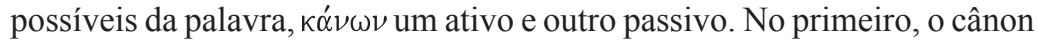
é a coleção dos livros que contém a norma cristã de fé e de vida (norma normans), no primeiro sentido, supõe-se que os livros do cânon possuam um valor intrínseco, que está enraizado em sua própria origem e natureza e é anterior ao fato de terem sido reunidos numa coleção. ${ }^{13}$

c) a leitura da Bíblia e a profissão de Fé eram, na antiga Igreja, atos próprios do culto de toda a comunidade. ${ }^{14}$

d) O decisivo como característica, no entanto, como bem enfatiza Bauer, é o cânon ser uma 'justificação racional', dando à Fé, aspectos de pensamento:

${ }^{12}$ BAUER, La exégesis del Nuevo Testamento y su trajectoria, p.45.

13 TREBOlle J. B.A Bíblia Judaica e a Bíbila Cristã. Petrópolis: Vozes, 1993; p. 297. METZGER, B. M. The Canon of the New Testament. $2^{\text {a }}$ Ed. Oxford: Clarendon, 1992, p. 252: "A basic prerequisite for canonicity was conformity to what was called the 'rule of the faith'

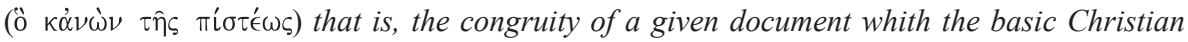
Tradition recognized as normative by the Church." Um texto importante para a questão é HÄGGLUND, $B$. "Die Bedeutung der 'regula fidei' als Grundlage theologischer Aussage". Studia Theologica XXI (1958), pp. 1-44; BORGONONO, G. "Una proposta di rilettura dell'Ispirazione bíblica dopo gli apporti della Form-e Redakstionsgeschichte". In: GRECH, P. et Alii(ed.). L'Interpretazione della Bibbia nela Chiesa, pp. 41-62.

14 REISER, M. "Die Stellung der Evangelien in der antiken Literaturgeschichte". ZNW 90 (1999), pp. 1-27. A relação entre a Liturgia e a vida no Cristianismo Primitivo: DOS SANTOS, P. P. A. "A Profecia Cristã no Novo Testamento: Uma Tentativa de Reconstrução do Fenômeno da Profecia cristã no Cristianismo Primitivo". Atualidade Teológica 6/7 (2000), pp. 71-101, neste artigo tratamos do lugar do profeta, que no contexto do Cristianismo Primitivo ilumina e atualiza no culto, as Escrituras cristãs para a Comunidade. No Apo 1, 10, no dia do Senhor, ocorre a visão e escuta da Palavra do Ressuscitado a João e à sua Igreja; DOS SANTOS, P. P. A. "O Apocalipse Cristão e os Rolos de Qumran. Literatura e Movimentos apocalípticos no Mundo Antigo e suas relações com Projetos Contemporâneos". Communio 22/1 (2004), pp. 134-156. No período patrístico: RICCI, C. La "Profezia in Gregório Magno". Patristicum 43 Roma, (2003), pp. 125-200. 
Com o Cânon, as profissões de fé e as formas fundamentais de culto, os Padres não criaram apenas estes três elementos básicos da vida cristã, mas que eles conceberam a fé como uma espécie de filosofia, decidir-se assim, por uma justificativa racional para a mesma. ${ }^{15}$

Passaremos agora à análise do contexto histórico e literário da produção exegética e patrística Grega, com suas escolas e problemas teológicos específicos.

\section{As escolas de Alexandria ${ }^{16}$ e Antioquia ${ }^{17}$}

Com Clemente ${ }^{18}$ e Orígenes ${ }^{19}$ pode-se falar da fundamentação da Hermenêutica baseada no método alegórico.

15 BAUER, La exégesis del Nuevo Testamento y su trajectoria, p.46: Con el canon, las profesiones de fe y las formas fundamentales del culto, los padres no crearon solamente éstos tres elementos básicos de la vida cristiana, sino que concibieron la fe como una especie de filosofía, decidiéndose así por una justificación racional de la misma.

${ }^{16}$ Destaco alguns textos escolhidos na lógica expositiva de nossa pesquisa, voltada para os aspectos da recepção e do ato de leitura: DORIVAL, G. et LE BOULLEUC, A. Origeniana Sexta. Origène et la Bible. Louvain, 1995; FONTAINE, J. "Come si deve applicare la nozione di gênero letterario alla letteratura cristiana del IV secolo?” Philologus 132 (1998), pp. 53-73; G. CAVALLO, G. "Scuola, Scriptorium, Biblioteca a Cesarea". nel Mondo Antico e Medievale. 2a Ed. Roma-Bari: Laterza, 2004, pp. 67-78.

17 À questão dos textos que teriam sido utilizados pelos Padres Gregos, é necessário propor uma verificação, através dos elementos oferecidos pela evolução da 'crítica textual: FEE, G.D. "The Text of John in Origen and Cyril of Alexandria: Analysis of Patristic Citations". In: EPP, E. J. and FEE, G.D. Studies in the Theory and Method of New Testament Textual Criticism. Michigan: Eerdermans, 1993, pp. 301-34. É indispensável a leitura do Festschrift oferecido a Jean Delobel para uma visão mais ampla da questão da tradição textual que se pode obter testemunhada nos Padres, em particular na Patrologia Grega, DUPLACY, J. Citations patristique et critique textuelle du Nouveau Testament. À propôs d'um livre récent. Louvain: BETHEL 78, 1987, Louvain, pp. 15-24; Études de Critique Textuelle du Nouveau Testament. Texte du Nouveau Testament. Quelques réflexions méthodologiques'. Études de Critique Textuelle du Nouveau Testament. Louvain: BETHEL 78, 1987, Louvain, pp. 39-54.

${ }^{18}$ NARDI, C. Il Battesimo in Clemente Alessandrino. Roma: SEA 19, 1984, um estudo referente à obra exegética neotestamentária de Clemente: CARLSON, S. C. "Clement of Alexandria on the 'Order' of the Gospel”. NTS 47 (2001), pp. 118-125.

${ }^{19}$ BUCHINGER, B. “1Kor 5,7 als Schlüssel der Paschatheologie des Origenes. Das Pascha der Juden, das Opfer Christi und das Pascha der Christen - eine Aporie?" ZNW 91 (2000), pp. 238-64. REVENTLOW, H.G. "Il cammino dell'anima alla perfezione: Origene". Storia dell'interpretazione biblica. Dall'Antico Testamento a Origene, vol.1. Monferrato: Piemme, 1999, pp. 230-260; SIMONETTI, M. "Sulla Teologia Trinitária di Origene“" Studi sulla Cristologia del II e III secolo, Roma, 1993, pp. 109-44; . também Orígenes nos oferece exegese 'joanina'; CROUZEL, H. 'L'Évangile de Jean et la Patristique: L'Exégèse Origénienne de Jn 413-15“. In: MARCHADOUR, A. Origine et Posterité de l'Évangile de Jean. Paris: Du Cerf, 1990, pp. 163-72. 


\subsection{Filão de Alexandria ${ }^{20}$}

O judeu Filão precedera esta escola, pois refutava o sentido óbvio e literal da Escritura. Através do sentido alegórico ele entendia superar os passos obscuros e abrir a inteligência das Escrituras.

A alegoria entendida por Filão era, sobretudo, baseada numa perspectiva vertical: o sentido literal refere-se ao conteúdo moral, enquanto as realidades terrestres se referem às celestes.

Neste sentido a escola de Alexandria, de Orígenes e Clemente, desenvolveu a dimensão temporal da alegoria convertida em tipologia, ao considerarem todo o A.T. como pré-figuração da Nova Aliança.

\subsection{Clemente de Alexandria e Orígenes ${ }^{21}$}

Clemente de Alexandria ofereceu-nos através do método alegórico uma interpretação cristocêntrica do AT. Para essa escola, a Escritura possui uma infinidade de sentidos, literal, moral, espiritual, etc.

La exégesis patristica se caracteriza por la actividad de dos escuelas exegéticas: por una parte está el didaskaleion de Orígenes en Alexandria, el cual difiende un triple sentido en la Escritura y busca de diferentes maneras las interpretaciones alegóricas y tipológicas ${ }^{22}$.

Segundo Orígenes ${ }^{23}$, a Escritura entende revelar verdades intelectuais e não tanto narrar as intervenções de Deus no curso da História, mesmo porque esta, muitas vezes, não faz mais do que ocultar a Revelação.

Ele refuta o sentido literal como suficiente para entender as Escrituras, por um princípio de racionalidade; tudo isso para afirmar a primazia do sentido da Fé:

${ }^{20}$ TERMINI, C. Le potenze di Dio. Studio su dunamis in Filone di Alessandria. Roma, 2000; SIMONETTI, M. Lettera elo Allegoria. Un contributo alla Storia dell'Esegesi Patristica. Roma, 1985; PÉPIN, J. La Tradition de l'Allegorie de Philon D'Alexandrie a Dante. 2 tomes. Paris: Études Augustiniennes, 1987.

${ }^{21}$ PRINZIVALLI, E. Magister ecclesiae. Il dibattito su Origene fra III e IV secolo, Roma: SEA 82, 2002.

${ }^{22}$ BAUER, La exégesis del Nuevo Testamento y su trajectoria, p. 38.

${ }^{23}$ Tem sido intenso o esforço de muitos estudiosos em recuperar a teoria e a tradição exegéticas deixadas por Orígenes: BASTIT-KALINOWSKA, A. "L'Interprétation de l'évangile comme récit dans le Commentaire sur Matthieu d'Origène". La Narrativa Cristiana. Codici Narrativi, Strutture Formale, Schemi retorici. Roma: SEA 50, 1995, pp. 267-282. 
Daí em diante foi impossível se livrar dos múltiplos princípios da Escritura e se buscou sem sucesso, embora com grande constância, um meio termo entre o sentido literal, pouco considerado e as fantasias alegóricas que tampouco, inspiravam muita confiança. ${ }^{24}$

\subsection{A Escola de Antioquia}

Aparentemente do lado oposto estava a Escola de Antioquia ${ }^{25}$. Nela destaca-se o nome de Teodoro de Mopsuéstia. Influenciada pelas correntes do Judaísmo, esta Escola, traduziu o retorno ao sentido literal e histórico da Escritura: "O sentido literal era primário, e era dele que as lições morais deveriam ser retiradas, os sentidos tipológico e alegórico, ainda que não fossem excluídos, eram secundários"26.

Para a exegese antioquena as profecias bíblicas tinham um duplo sentido: aquele histórico e messiânico ao mesmo tempo. Eles propunham a interpretação literal e filológica dentro do marco da história da Salvação. O sentido 'cristocêntrico' das profecias estava no texto e não era algo sobreposto a ser descoberto somente através do recurso à alegoria ${ }^{27}$.

Juntamente com Theodoro deverá marcar o método literal, João Crisóstomo (+417), “cujas interpretações exegéticas constituem uma das principais fontes das catenae e converteu-se no maior defensor da exegese antioquena"28

\footnotetext{
${ }^{24}$ BAUER, La exégesis del Nuevo Testamento y su trajectoria, p.39: "En adelante fue impossible desprenderse del princípio múltiple de la Escritura, y se buscó sin mucho éxito, aunque con grande constancia, un camino intermedio entre el sentido literal, tenido en poco, y las fantasias alegóricas que tampoco acababan de inspirar mucha confiança".

${ }^{25}$ DE NAVASCUÉS, P. "Pablo de Samosata y sus adversarios. Estudio històrico - teològico del cristianesimo antioqueno en el siglo III". Roma: SEA 87, 2004, ROUX, R. L'exégèse biblique dans les Homélies cathédrales de Sévère d'Antioche. Roma: SEA 84, 2002, FATICA, L. I Commentari a Giovanni di Teodoro di Mopsuestia e di Cirillo di Alessandria. Roma: SEA 29, 1988.

${ }^{26}$ BRUCE, F. F. The History of New Testament Study. New York: Doubleday, 1969, p. 26: 'The literal sense was primary, and it was from it that moral lessons should be drawn, the typological and allegorical senses, while not excluded, were secondary'.

${ }^{27}$ MARSCHAL, I. H. (ed.). New testament Interpretation. Essays on Principles and Methods. $3^{\text {a }}$ Ed. Carlisle: Paternoster, 1992, p. 21-59; LONGENECKER, R. N. "The Nature of New Testament Exegesis". In: Biblical Exegesis in the Apostolic Period. $2^{\mathrm{a}} \mathrm{Ed}$. Michigan: Grands Rapids, 1999, pp. 185-198; ALETTI, J.-N. Jésus-Christ fait-il l'Unité du Nouveau Testament? Paris: Du Cerf, 1994.

${ }^{28}$ TREBOLLE, Biblia Judaica e Bíblia cristã, p. 640.
} 
Ambas as escolas de exegese encontram-se do mesmo lado, seja na alegoria que centra em Cristo toda a verdadeira compreensão das Escrituras, seja na interpretação literal.

Elas não se afastam do Cânon como regra da fé, e por isso constituem esforços racionais de exprimir e apoderar-se do dado revelado.

Elas fundam no interno da mesma Igreja (contrária às heresias que formam igrejas à parte) um princípio racional que leva ao espírito da Letra Sagrada $^{29}$ :

$\mathrm{Na}$ hora de estabelecer o critério para saber se uma passagem devia ser interpretada literalmente ou não, recorria-se à regula fidei e a um princípio racional: não é válido interpretar literalmente uma passagem que seja absolutamente contrária à razão.

A regra da fé constitui-se em critério tanto para a Escritura, cuja fonte é a Revelação, como para a Filosofia, cuja fonte é a razão. Fílon e os Padres cristãos conheciam a ideia da subordinação da Filosofia à Escritura, simbolizadas nas figuras de Agar, a escrava, e de Sara, a senhora ${ }^{30}$.

É dentro deste ambiente com suas diversas visões do desenvolvimento do Cânon, da interpretação, e, sobretudo, com as transformações que o Cristianismo sofrerá a partir do momento em que se torna 'religião oficial' no Império Romano, que se insere a (história da) leitura exegética do Apocalipse.

\section{Uma Breve História da Recepção 'canônica' do Apocalipse A $^{31}$}

O Apocalipse é sem dúvida um livro fascinante, quem se deixa prender pela riqueza de seus símbolos e se empenha em descobrir-lhe a estupenda tecitura na multiplicidade dos seus particulares, consegue colher a beleza da ardil arquitetura literária e degustar a arte de sua comunicação por imagens. Mesmo assim o Apocalipse desconcerta: muitos leitores desistem de lê-lo,

${ }^{29}$ AGOURIDES, S. "The Regula Fidei as Hermeneutical Principle Past and Present". In: GRECH, P. et Alii (ed.). Il Messaggio Biblico e la sua Interpretazione, p. 225-313.

${ }^{30}$ TREBOLLE, Biblia Judaica e Bíblia cristã, p. 642.

${ }^{31}$ MARUCCI, C. La Canocicità dell'Apocalisse nel Primo Milennio. In: COLACRAI, E. B. Percorsi nell'Apocalisse di Giovani. Assisi: Cittadella, 2005, pp. 649-676; IRMSCHER, J. "La Valutazione dell'Apocalisse nella Chiesa Antica". Augustinianum, Roma, 1988, pp. 171-176; GRYSON, R. "Les Commenatires Patristiques Latins de L'Apocalypse". Revue Théologique de Louvain 28, 1997, pp. 484-502, L'Apocalypse expliquée para Cesaire D'Arles. DDB, Paris: Bouwer, 1989. 
por considerá-lo incompreensível ou louco. Efetivamente a comprensão do último livro da Bíblia não é uma obra simples; também os antigos perceberam isso, e em todos os séculos até hoje muitos têm se aprofundado em sua interpretação. São Jerônimo apresenta o Apocalipse como superior a qualquer elogio possível, mas reconhece com uma fórmula sintética e expressiva, que toda a sua escritura constitui um enigma, porque todas as expressões querem comunicar um mistério ("Tot habet sacramenta quot verba") ${ }^{32}$.

'Tot habet sacramenta quot verba': "Cada palavra quer expressar um Mistério". Esta é a chave crítica oferecida por um arguto leitor das Escrituras, São Jerônimo. Mais do que qualquer outro livro do Cânon do Novo Testamento, o Apocalipse explora o força da palavra simbólica, translúcida e 'subversiva', o que exige da razão (exegética) um esforço imenso de maleabilidade e argúcia para lidar com os meandros da (autêntica) mensagem deste livro.

\subsection{A Recepção do Livro na Antiguidade: Entre acolhida e hostilidade}

A obra de João exercitou desde o princípio um significativo influxo literário e teológico sobre os escritores eclesiásticos, de fato, já nas obras dos Padres Apostólicos se podem encontrar imagens e expressões que muito provavelmente dependem do Apocalipse. A partir do $\mathrm{II}^{\circ}$ século ele resulta comumente aceito em todas as Igrejas e citado como Escritura inspirada por todos os principais autores cristãos ${ }^{33}$.

Segundo Doglio a grande difusão do livro do Apocalipse, lido e estimado por tantos cristãos, explica-se, sobretudo, com a ajuda e o encorajamento que este oferecia às comunidades cristãs nos difíceis séculos de perseguições e de não reconhecimento do Cristianismo, por parte do Estado Romano.

32 DOGLIO, C. Duemila anni di tentativi! Storia dell'interpretazione dell'Apocalisse. In: Parole di vita 45/6 (2000) p. 4: L'Apocalisse è senza dubbio un libro affascinante: chi si lascia prendere dalla ricchezza dei suoi simboli e si impegna a scoprirne la mirabile tessitura nella molteplicità dei particolari, riesce a cogliere la bellezza dell'ardita architettura letteraria e a gustare l'arte della comunicazione per immagini. Eppure l'Apocalisse sconcerta anche: più di un lettore ha smesso di leggerla, ritenendola incomprensibile o folle. Effettivamente la comprensione dell'ultimo libro della Bibbia non è opera semplice; anche gli antichi se ne erano accorti e in tutti i secoli, fino ad oggi, molti si sono cimentati nella sua interpretazione. San Girolamo presenta l'Apocalisse dicendola superiore a ogni possibile elogio, ma riconoscendo, con una formula sintetica ed espressiva, che ogni sua parola costituisce un enigma, proprio perché ogni espressione vuole comunicare un mistero «Tot habet sacramenta quot verba».

${ }^{33}$ DOGLIO, C. Duemila anni di tentativi, p. 5. 
De fato, a mensagem marcada pela carga combativa, contida no Apocalipse, sobretudo, como crítica radical do poder corrompido, foi de grande auxílio aos cristãos nos tempos difíceis de conflito com o poder romano: estes eram de fato uma minoria desprezada e era claro para todos quem fosse o inimigo opressor.

Em tais situações os leitores-crentes se sentiam os seguidores do "Cordeiro Imolado e vencedor", extraindo da leitura orante forças para prosseguir em seu pacífico testemunho.

Além disso, o pensamento "catastrófico' do Apocalipse impressionou fortemente os leitores e em particular, o símbolo apocalíptico do "milênio" tornou-se desde o fim do $\mathrm{II}^{\circ}$ século um elemento determinante no panorama teológico e literário da comunidade cristã.

Sua interpretação, literal ou alegórica, presente ou futura, divide os autores eclesiásticos e produz contestações, críticas e refutações: muitos comentadores, de fato, interpretaram o milênio de Apoc $20^{34}$ no sentido literal, transmitindo aos seus grupos o desejo de ver realizado em breve, na terra, este sonho de vida paradisíaca.

Mas, com a situação do Edito Constantiniano ( $\mathrm{IV}^{\circ}$ século) estas coisas mudaram: os cristãos se tornaram maioria e a literatura apocalíptica retornou a ser apanágio de minorias.

Exatamente no início do $\mathrm{IV}^{\circ}$ século, de fato, o Apocalipse começou a ser usado de modo intensivo pelos movimentos heréticos, sobretudo, por seitas milenaristas em polêmica com a grande Igreja.

Enquanto perde sua força incisiva sobre as comunidades, agora fortes e reconhecidas pelo Estado, o Apocalipse conserva a sua carga revolucionária para os pequenos grupos que continuam a sonhar, de diversos modos, com a renovação do mundo.

Por isso, o texto de João se torna suspeito e alguns autores eclesiásticos se empenham em redimensionar a sua importância: os grupos contestadores que o estão utilizando serão marginalizados pelas autoridades da Igreja.

Assim, por exemplo, no Egito, onde o Apocalipse sempre teve grande crédito, esta interpretação revolucionária foi contestada por Dionísio, Bispo de Alexandria. Em torno de 250, ele se encontrava em contraste com o ensinamento cismático de Nepote, Bispo de Arsinoe, que sustentava a interpretação literal do milenarismo e usava o Apocalipse como seu fundamento bíblico.

\footnotetext{
${ }^{34}$ MAZZUCCO, C. e PIETRELLA, E. La Concezione del Millennio e L'Apocalisse di Giovanni. Augustinianum 18/1, (1978), p. 29-45.
} 
Dionísio, portanto, assumiu o estudo do Apocalipse, não para conhecer o texto em si, mas em chave polêmica, para opor-se a una leitura superficial e literal, pensando nos fundamentalistas do seu tempo, que tantos problemas causavam à sua Igreja, e para convidar-lhe a um estudo sério e aprofundado, de modo a poder colher o sentido profundo e simbólico do texto.

Não se pode esquecer dos Montanistas ${ }^{35}$, que irão influenciar diversos setores da Igreja Síria, envolvendo nomes de relevo, como Tertuliano ${ }^{36}$. Tudo isso, terá reflexos na recepção do Apocalipse, inclusive, com a oposição de Eusébio de Cesareia.

Heresias, dificuldades de interpretação, perturbações eclesiais, todas estas incertezas explicam o silêncio de muitos Padres Gregos em relação ao Apocalipse e a ausência de antigos comentários a este livro estupendo! ${ }^{37}$

Assim, na Síria, devido ao uso desequilibrado que faziam os montanistas, o Apocalipse não gozava de boa reputação e o grande histórico Eusébio de Cesareia, que viveu na época de Constantino, mostrava-se desfavorável a este livro: é ele, de fato, que refere as objeções contra o autor do Apocalipse por Dionísio d'Alexandria, porque entendia ter encontrado um bom argumento para subtrair o valor e a credibilidade de um livro incômodo. Nestas circunstâncias, o texto da Apocalipse, objetivamente

\footnotetext{
${ }^{35} \mathrm{O}$ Montanismo foi uma antiga heresia que se originou no século II, e se espalhou da Frigia, na Ásia menor, estendendo-se em todo o Oriente Médio, sobreviveu até o século VI. Este nome vem do seu fundador, Montano, um antigo sacerdote da deusa Cibele, que acreditava ser o único capaz de interpretar corretamente o Evangelho de João, pretendendo assim, ser reconhecido como a personificação do Consolador (Paráclito), prometido por Jesus. ALAND, B. "Montano - Montanismo". Dicionário Patrístico e de Antiguidades Cristãs. Petrópolis/São Paulo: Vozes/Paulus, 2002, pp 959-961; CZESZ, B. "La "tradizione" profética nella controvérsia montanista". In: Sogni, Visioni e Profezie nell'antico Cristianesimo. Roma Augustinum, 1989, pp. 55-70; sobre os textos dos 'montanistas': SIMONETTI, M. “Oracoli Montanisti”. In: . Letteratura Cristiana Antica. I vol. Casale Monferrato: Piemme, 1996, pp. 206-211.

36 Tertuliano pode ser considerado um exemplar da situação do avanço e do prestígio de ambientes heréticos na esfera da Igreja latina: SIMONETTI, M. Tertuliano. In:

Letteratura Cristiana Antica. I vol. Casale Monferrato: Piemme, 1996, pp.780-842; SIMONETTI, M. L'Esegesi Patristica in Occidente: Caratteri e Tendenze. In:

L'Esegesi dei Padri Latini. Roma, 2000, 7-22.

${ }^{37}$ Sobre a mentalidade 'milenarista', cultura escatológica', terreno comum de crenças entre cristãos e pagãos nos séculos II e III a.C: TRISOGLIO, F. "Eusebio di Cesarea e l'Escatologia”. Augustinianum 18/1 (1978), pp 173-182; CATAUDELLA, Q. "I cristiani e l'oltretomba pagano". Augustinianum 18/1 (1978), pp.7-2; FILORAMO, G. "Rivelazione ed Escatologia nello Gnosticismo Cristiano del II secolo". Augustinianum 18/1 (1978), pp. 75-88.
} 
difícil de explicar e facilmente mal interpretado por vários hereges, vinha transcurado e, próprio por oposição às seitas, se preferia ignorá-lo ou denegri-lo ${ }^{38}$.

Sobre o percurso dos Comentários mais importantes sobre o Apocalipse, dentro da perspectiva já estabelecida, é preciso sempre reafirmar que estes textos não existem no vácuo, ou por vaidade erudita de um autor isolado, mas que constituem verdadeiras redes de comunicação das inquietações, das necessidades, das disputas políticas e conflitos intelectuais que perpassam a história da interpretação de um livro.

Iniciaremos com a pesquisa dos Comentários Gregos, mais raros, em um período decisivo da Igreja primitiva, aquele posterior ao difícil sodalício com o Império Romano, ambiente que favorecera uma leitura 'bélica' do texto apocalíptico, expondo uma verdadeira 'eclesiologia militante ${ }^{39}$.

\subsection{A Leitura antiga do Apocalipse na Igreja Grega (Oriental)}

Somente no século VI na Igreja grega aparece um comentário completo sobre o Apocalipse e é obra de um escritor não Calcedonense chamado Ecumenius, que não teve grande influência; em vez disso, no final do mesmo século, Andrea, Bispo de Cesárea, escreveu o clássico comentário bizantino (Herméneia eis ten Apokálypsin), que, no século X foi retomado pelo seu sucessor, Aretas, tornando-se o monumento exegético da tradição grega sobre o Apocalipse. Sua interpretação é de tipo histórico, com

\footnotetext{
${ }^{38}$ DOGLIO, C. Duemila anni di tentativi, p. 5: 'Così in Siria, dato lo squilibrato uso che ne facevano i montanisti, l'Apocalisse non godeva buona reputazione e il grande storico Eusebio di Cesarea, vissuto all'epoca di Costantino, si mostra non favorevole a questo libro: è lui, infatti, che riporta le obiezioni mosse all'autore dell'Apocalisse da Dionigi d'Alessandria, perché ritiene di avervi trovato uno spunto buono per togliere valore e credibilità a un libro scomodo. In tal modo, il testo dell'Apocalisse, oggettivamente difficile da spiegare e facilmente frainteso da eretici vari, veniva trascurato e, proprio per opposizione alle sette, si preferiva ignorarlo o denigrarlo'.

${ }^{39}$ Muito interessante estabelecer a visão da Igreja como uma comunidade escatológica, envolvida com o fim dos tempos: ROLOFF, J. "Die Kirche als Zeugnis der endzeitlichen Königsherrschaft Gottes: Die Offenbarung des Johannes”. In: . Die Kirche im Neuen Testament. Göttingen: Vandenhoeck \&Ruprecht, 1993, pp. 144-168; Uma visão da Eclesiologia do Novo testamento e em particular nos escritos Joaninos: DOS SANTOS, P. P. A.. "O Apocalipse de Jesus Cristo. Testemunho e Espírito da Profecia. A Tradição e a Eclesialidade joaninas como fonte e testemunho na busca de Traços do Cristianismo Primitivo". Atualidade Teológica 8 (2001), pp. 39-51.
} 
frequentes referências a episódios da vida de Cristo, mas o mais importante, alegórico, usando muitas figuras para esclarecer a história da salvação ${ }^{40}$.

A difícil situação em que se encontrava a recepção do livro do Apocalipse após o século IV, em ambiente grego, com a persistência de uma leitura ainda alegorizante e antirromana por parte de diversos ambientes eclesiais com uma acentuada identidade milenarista, explica os acentos de caráter 'teológicodogmático', que marcam a produção de comentários exegéticos gregos ${ }^{41}$.

Travava-se na superfície do texto, nas malhas da análise literária do apocalipse, uma batalha em torno de estabelecer uma gramática do símbolo que se comporta com mais nuance diante do novo mundo posconstantiniano.

Neste período, o exegeta do Apocalipse (muitas vezes Bispo envolvido em lutas doutrinais e de poder) está interessado em conduzir uma leitura do símbolo apocalíptico, que organize a realidade sem conflitos, naqueles tempos de 'pax'. E por isso, elabora-se uma leitura que dialoga com os matizes acentuados da profecia do passado, substituindo assim, uma exegese apocalíptica de um ambiente que até então queria o texto joanino como aliado em estratégias de 'guerrilha social' contra o Império Romano, a sociedade e a religião pagã $\tilde{a}^{42}$.

${ }^{40}$ DOGLIO, C. Duemila anni di tentativi, p. 6: 'Solo nel VI secolo compare nella Chiesa greca un commento completo all'Apocalisse ed è opera di uno scrittore non calcedonese di nome Ecumenio, che non ebbe quindi un grande influsso; invece alla fine dello stesso secolo Andrea, vescovo di Cesarea, compose il commento classico bizantino (Herméneia eis ten Apokálypsin), che, ripreso nel X secolo dal suo successore Areta, resta il monumento esegetico della tradizione greca sull'Apocalisse. La loro interpretazione è di tipo storico, con frequenti riferimenti a episodi della vita di Cristo, ma soprattutto allegorico, con l'utilizzo abbondante di figure per chiarire la storia della salvezza'.

${ }^{41}$ IRMSCHER, J. "La Valutazione dell'Apocalisse nella Chiesa Antica". In: Sogni, Visioni e Profezie nell'antico Cristianesimo. Roma: Augustinianum, 1989, pp. 171-176; MARUCCI, C. "La Canocicità dell'Apocalisse nel Primo Milennio". In: COLACRAI, E. B. Percorsi nell'Apocalisse di Giovani. Assisi: Cittadella, 2005, pp. 649-676; UBIERNA, P. 'Recherches sur l'apocalyptique syriaque et byzantine auvii siècle: la place de l'Empire romain dans une histoire du salut'. Bulletin du centre d'études médiévales d'Auxerre (BUCEMA), Hors-série $n^{\circ} 2$ (2008); CZESZ, B. 'La "tradizione” profética nella controvérsia montanista'. In: Sogni, Visioni e Profezie nell'antico Cristianesimo. Roma: Augustinianum, 1989, pp. 55-70.

42 DOS SANTOS, P. P. A. O Apocalipse Cristão e os Rolos de Qumran. Literatura e Movimentos apocalípticos no Mundo Antigo e suas relações com Projetos Contemporâneos. Communio (2004), pp. 133-156. 
Uma nova ordem social e mundial invade a exegese do livro sem amarras, aberto ao insólito e sedutor às franjas radicais cristãs na Igreja primitiva. Uma exegese na contramão da utopia escatológica dos primeiros três séculos ${ }^{43}$.

Será por isso que o século $\mathrm{VI}^{\circ}$ irá acolher uma gramática (des) apocalíptica deste Livro 'rebelde' entre os Gregos, com a aparição do Comentário de Ecumênio, interrompendo um jejum exegético da inteligência desta 'região' literária tão complexa do Novo Testamento?

Segundo Doglio, será necessário o século XII na Tradição Bizantina, para conhecer o primeiro comentário de um autor de siríaco, Dionísio Bar Salibi, morto em 1171. Ele, como Bispo de Amida, quer explicar o Apocalipse, recuperando as antigas interpretações de Hipólito ${ }^{44}$, a fim de compreender o significado dos acontecimentos problemáticos contemporâneos ao Bispo siríaco $^{45}$.

Mazzucco e Pietrella ${ }^{46}$ afirmam que pode e deve ser contestada a consideração difundida por Eusébio de Cesário no mundo grego, de que o Apocalipse teria uma 'raiz' milenarista', talvez por sua origem duvidosa, atribuível a Cerinto, e por isso, tornara-se um livro dado a movimentos heréticos, muito antes de ser ultrapassado pela 'revolução constantiniana' que irá inverter os papeis da Igreja na tardia sociedade romana.

Para estes pesquisadores, baseados nas escassas e ambíguas fontes de referências, citadas pelos detratores do livro do Apocalipse, ligando-o diretamente a Cerinto ${ }^{47}$ Papias $^{48}$, montanistas e milenaristas, em geral, não se pode afirmar que o berço do livro apocalíptico do Novo Testamente seja originariamente 'herético'.

\footnotetext{
${ }^{43}$ MONACI, A. Apocalisse ed Escatologia in Origene Augustinianum 18/1 (1978), pp. 139-151. ${ }^{44}$ Vale a leitura deste artigo que explora a recepção de um escrito 'escatológico' em uma nova realidade desconstruindo o milenarismo: ANDREI, O. "Dal De Antichristo di Ippolito al De Consummatione mundi del PsIppolito: "riscrivere" um texto e "comunicare storia". Communicazione e Ricezione del Documento Cristiano in Epoca Tardoantica. Roma: Studia Ephemeridis Augustinianum 90, 2004, pp. 89-119.

45 JIMÉNEZ, F. M. F. El Comentario sobre el Apocalipsis" de Ecumenio en la controversia cristológica del siglo VI en Bizancio. Madrid: San Damazo, 2013.

${ }^{46}$ MAZZUCCO, C. e PIETRELLA, E. "La Concezione del Millennio e L'Apocalisse di Giovanni”. Augustinianum 18/1, (1978), p. 30.

${ }^{47}$ KLIJN, A. F. J. "Cerinto e cerintianos". Dicionário Patrístico e de Antiguidades Cristãs. Petrópolis/São Paulo: Vozes/Paulus, 2002, p. 285.

48 VANYÓ, L. "Pápias de Hierápolis". Dicionário Patrístico e de Antiguidades Cristãs. Petrópolis/São Paulo: Vozes/Paulus, 2002, p. 1087.
} 
Três seriam as hipóteses de fundo que explicariam esta má impressão causada à inteligência bizantina e que provocará, praticamente a 'exclusão' deste livro na liturgia e na fileira dos comentários exegéticos dedicados a ele, ao menos até o VI século:

1) $\mathrm{O}$ estabelecimento preciso entre o milenarismo de autores como Cerinto e Papias com o Apocalipse foi estabelecido 'a posteriori', pelos adversários da obra joanina;

2) Esta operação se insere em um contexto polêmico, no conspecto de pessoas e ideias pertencentes a movimentos apocalípticos e em relação às orientações eclesiásticas e políticas direcionadas para o reforço das estruturas da Igreja, no sentido hierárquico e para uma conciliação com o Império;

3) O objetivo era atingir o texto do Apocalipse, não tanto porque fosse (considerado) milenarista, quanto por sua matiz profética e apocalíptica, no sentido contestador da palavra.

\subsection{Herméneia eis ten Apokálypsin de Ecumênio ${ }^{49}$}

Nunca um livro no mundo foi mais comentado quanto o Apocalipse, mas em sentidos tão díspares que não se pode, sem criar certa provisão de coragem, tentar traçar a história das interpretações ${ }^{50}$.

Segundo Castagno os comentários ao Apocalipse de Ecumênio e de André de Cesaréia são os mais antigos da tradição exegética Oriental que nos chegaram integralmente. É verdade, que outros escritos sobre o Apocalipse foram escritos, como nos refere Eusébio de Cesaréia acerca de Melitão, que escreveu mais de uma obra sobre os demônios e sobre o Apocalipse ${ }^{51}$.

Já apontamos que havia muita desconfiança sobre o Livro do Apocalipse, e não havia unanimidade, nem mesmo quanto à sua canonicidade ${ }^{52}$.

${ }^{49}$ CASTAGNO, A. M. "I Commenti di Ecumenio e di Andrea di Cesarea: Due letture Divergenti dell'Apocalisse". Memorie dell'Accademia delle Scienze di Torino. Serie V. vol. 5, 1981, pp. 306-426; E em parte, SIMONETTI, M. Lettera elo Allegoria. Un Contributo Alla storia dell'esegesi patrística. Roma: Patristicum, 1985.

${ }^{50}$ ALLO, E.-B. Saint Jean. L'Apocalypse. Paris: Gabalda, 1921, p. CCXVI: 'Pas un livre au monde n'a été plus commenté que l'Apocalypse, mais en des sens si diverse qu'on ne peut pas, sans faire une certe provision de courage, se mettre à tracer l'histoire des interpretations'.

${ }^{51}$ EUSB. H. E. IV, 26.2. SIMONETTI, M. "Eusebio di Cesarea". In: . Letteratura Cristiana Antica. 2 vol. Casale Monferrato: Piemme, 1996, pp. 48-112, espec. "Critica filologica di Dionigi al texto dell'Apocalisse", pp. 105-112.

52 MARUCCI, C. “La Canocicità dell'Apocalisse nel Primo Milennio”. In: COLACRAI, E. B. 
A questão da crítica patrística grega encontra-se na encruzilhada do 'milenarismo' e suas consequências político-religiosas ${ }^{53}$ criadas com as novas relações entre o Império Romano e a Igreja após Constantino.

Mas antes de todos será o grande Orígenes a opor-se a estas interpretações milenaristas ${ }^{54}$.

O que distingue a Orígenes dos autores que o precederam é uma intuição diversa do texto apocalíptico: Aqueles colheram, acima de tudo, o tradicional, que nele estava contido, Orígenes colhera nele o elemento novo que desconcertava a lógica tradicional e fêz deste o princípio unificador de sua exegese $\mathrm{e}^{55}$.

Monaci com outros autores, afirma que, diversamente de outros Padres como Irineu, Justino, Hipólito, Orígenes não compartilhava da convicção que a leitura do Apocalipse devesse privilegiar 'chialismo' ou milenarismo ${ }^{56}$.

Para a pesquisadora, Orígenes, em sua Cristologia, abandona a exegese literalista do texto apocalíptico, que isola a unidade discursiva, em favor de uma leitura alegórica do passado, numa perspectiva profética. Ele, por isso, baseado na centralidade do mistério de Cristo realizado em sua Encarnação redentora, dispensa uma visão catastrófica:

Percorsi nell'Apocalisse di Giovani. Assisi: Cittadella, 2005, pp. 649-676.

${ }^{53}$ Ao longo da História da religião a utopia expressa na crença milenarista, de fundo escatológico irá marcar a identidade e a ação de diversos grupos religiosos e seculares: CASTELLI, E. (cura). Ermeneutica e Escatologia. Roma, 1971; MILBANK, J. Theology \& Social Theory beyond Secular Reason. Oxford: Blackwell, 1993.

${ }_{54}$ MONACI, A. Apocalisse ed Escatologia in Origene Augustinianum 18/1 (1978), pp. 139-151. Especificamente sobre o Milenarismo e seus autores em relação ao Livro do Apocalipse: MAZZUCCO, C. e PIETRELLA, E. "La Concezione del Millennio e L'Apocalisse di Giovanni”. Augustinianum 18/1 (1978), pp. 29-45.

${ }_{55}$ MONACI, A. Apocalisse ed Escatologia, p. 150: 'Cio che distingue Origene dagli autori Che l'hanno preceduto é un'intuizione diversa del texto apocalittico: gli uni coglievano sopratutto cio Che di tradizionale in esso era contenuto, Origine vi aveva colto l'elemento nuovo Che scompaginava la lógica tradizionale e ne aveva fatto il principio unificatore della sua esegesi IRMSCHER, J. La Valutazione dell'Apocalisse nella Chiesa Antica'. MARUCCI, C. La Canonicità dell'Apocalisse nel primo Millenio, p. 659-660; numa perspectiva mais ampla do assunto: ALAND, B. "Die Rezeption des neutestamentlichen Textes in den ersten Jahrhunderten". In: SEVRIN, J.-M. The New Testament in Early Christianity. Louvain: Bril, 1989, pp. 1-38.

${ }^{56}$ DOS SANTOS, P. P. A. "O Discurso da Verdade” (alethés Lógos) em 'Contra Celso' (Orígenes). Um Debate 'Filosófico (-teológico)' Judaico-cristão no Império Romano do III $^{\circ}$ sec. d.C. In: DA SILVA, A. C. e DE LIMA, F. L. A linha e corte: tensões e transformações na antiguidade clássica e na cultura oriental. Rio de Janeiro: Metáfora, 2013, pp. 292-312. 
Há, portanto, uma estrita coerência dentro da atitude de Orígenes em relação aos textos apocalípticos, coerência que consiste em não perder de vista um mesmo ponto de referência, ou seja, a figura do Filho e sua Encarnação. ${ }^{57}$

Não perder de vista a Encarnação de Cristo como chave hermenêutica exegética do Apocalipse muda a perspectiva de interpretação de um texto apocalíptico.

Para o exegeta Alexandrino ${ }^{58}$, se Cristo se encarnou e assim nos uniu de novo a Deus (Ap 5,9), vivemos já no tempo escatológico, que sentido teria então prever prazos, prever sofrimentos terríveis e combates últimos e tremendos com as forças do mal?

Na perspectiva de Origens o único evento decisivo já ocorreu, daquele momento em diante, não existe senão uma lenta, mas contínua ascensão e retorno ao Pai, processo gradual que se estende através de um número infinito de 'eones' ${ }^{59}$, e que é regulado não pela queda deste ou daquele reino humano, mas do processo moral das criaturas.

\footnotetext{
${ }^{57}$ MONACI, A. Apocalisse ed Escatologia, p. 149: 'Vi è dunque uma coerenza rigorosa all'interno dell'atteggiamento di Origene nei riguardi dei testi apocalittici, coerenza che consiste nel non perdere mai di vista uno stesso punto di riferimento e, cioè, la figura del Figlio e la sua Incarnazione'. Textos Originianos em SIMONETTI, M. “Origine”. In:

Letteratura Cristiana Antica. I vol. Casale Monferrato: Piemme, 1996, pp. 529-576; . Studi sulla Cristologia del II e III secolo, Studia Ephemeridis Augustianum 44, Roma, 1993, pp. 109-144.

${ }^{58}$ Destaco alguns textos escolhidos na lógica expositiva de nossa pesquisa, voltada para os aspectos da recepção e do ato de leitura: DORIVAL, G. et LE BOULLEUC, A. Origeniana Sexta. Origène et la Bible, Louvain, 1995; BUCHINGER, B. „1Kor 5,7 als Schlüssel der Paschatheologie des Origenes. Das Pascha der Juden, das Opfer Christi und das Pascha der Christen - eine Aporie?" ZNW 91 (2000), pp. 238-64. REVENTLOW, H.G. "Il cammino dell'anima alla perfezione”: Origene. Storia dell'interpretazione biblica. Dall'Antico Testamento a Origene. vol.1. Monferrato: Piemme, 1999, pp. 230-60; METZGER, B. M. "Origins" The Canon of the New Testament. $2^{\text {a }}$ ed. Oxford: Clarendon, 1992, pp. 135-141; SIMONETTI, M. "Sulla Teologia Trinitária di Origene“. . Studi sulla Cristologia del II e III secolo. Studia Ephemeridis Augustianum 44 (1993), Roma, pp. 109-144; . La Morte di Gesù in Origine. Studi sulla Cristologia del II e III secolo. Studia Ephemeridis Augustianum 44 (1993), Roma, pp.145-82. Também Orígenes nos oferece exegese 'joanina'; CROUZEL, H. L’Évangile de Jean et la Patristique: L'Exégèse Origénienne de Jn 413-15. In: MARCHADOUR, A. Origine et Posterité de l'Évangile de Jean. Paris: Du Cerf, 1990, pp. 163-172.

${ }^{59}$ VANNI, U. Il tempo Ed Eternità nell'Apocalisse. Traccie per una riflessione Teologicobiblica. In: CASALEGNO, A. Tempo Ed eternità. In Dialogo com Ugo Vanni sj, Torino: San Paolo, 2002, pp. 25-72.
} 
A forte tensão escatológica na direção de uma 'renovatio universalis', presente nos textos apocalípticos, é portanto, compreendida por Origens como uma tensão entre escatologia realizada e futura.

Dito isso, voltamos a nos ocupar das páginas e características do Comentário de Ecumênio estudado a fundo pela Castagno.

Com insistência a pesquisadora italiana sublinha as metas deste comentário exegético grego.

Primeira, afirmar a unidade dos escritos sob a autenticidade joânica e com o resto das Escrituras, para afastar qualquer dúvida sobre a canonicidade do texto apocalíptico.

Segunda, demonstrar a 'pureza' doutrinal do livro do Apocalipse, sobretudo no contexto das lutas com Calcedônia por parte dos monofisitas ${ }^{60}$ entre outros.

${ }^{60}$ Um Concílio ecumênico foi reunido, convocado pelo imperador Teodósio II, Marciano (450-457), na cidade de Calcedônia, em 451. Nesse concílio, uma profissão de fé definia a natureza de Cristo, combatendo tanto nestorianos quanto monofisistas. Assim, o Concílio da Calcedônia definiu que: (...) o Filho e Nosso Senhor Jesus Cristo são um só e o mesmo, que Ele é perfeito na divindade e perfeito na humanidade, verdadeiro Deus e verdadeiro homem, com uma alma racional e um corpo, consubstancial com o Pai segundo a sua divindade e consubstancial conosco pela sua humanidade (...) Afirmava que em Cristo existiam duas naturezas, a divina e a humana, inconfundíveis e inseparáveis, numa única hipóstase (substância). Portanto, segundo o Concílio da Calcedônia, Cristo possui as duas naturezas, a humana e a divina, sem que a união anule a diferença. Essa definição ataca o monofisismo, ao afirmar ter Cristo as duas naturezas. A definição que ataca o nestorianismo se encontra no seguinte trecho: “ (...) nascido do Pai antes de todos os séculos segundo a Sua divindade (...)”, onde se afirma que Cristo não nasceu apenas como homem, sendo só mais tarde habitado pelo Verbo, como afirmava Nestório, mas que já nasceu divino. Assim, consolidava-se também a Maria o título de Theotokos, Mãe de Deus, e não mãe apenas da humanidade do Cristo. "(...) nascido da Virgem Maria, Mãe de Deus nestes últimos dias por causa de nós e da nossa salvação, de acordo com a sua humanidade". Vê-se por esse trecho a importância da condição humana de Cristo para a salvação. O texto do concílio finaliza reafirmando a consubstancialidade do Filho, e a indivisibilidade de suas duas naturezas, também inconfundíveis. A forte influência da cultura grega levou a população a questionar certas verdades pregadas pela Igreja Cristã, propiciando o surgimento de heresias dentro da Igreja do Oriente. As heresias questionavam os dogmas, (verdades) pregadas pela Igreja, e dentre elas vale destacar; o monofisismo e a Iconoclastia. a) Monofisismo: teve o seu apogeu no governo de Justiniano, e seus adeptos defendiam que Cristo possuía somente a natureza divina. b) Iconoclasta: Seus seguidores empenharam em destruir as imagens. Essa heresia ocorreu no governo do imperador Leão III, que buscando conter o poder do clero decretou ser proibido o uso de imagens nas igrejas. Outro motivo de descontentamento do papa com a Igreja do Império Bizantino, era o Cesaropapismo. Além disso, a Igreja do Oriente preferia celebrar o seu culto na língua grega, contrariando o papa, que deseja que os cultos fossem realizados em latim. As divergências entre a Igreja do Oriente e a do Ocidente acabaram provocando, em 1054, o Cisma do Oriente, isto é, uma cisão (separação), surgindo duas igrejas: a Igreja Ortoxa Grega, subordinada ao patriarca, e a Igreja Católica Apostólica Romana, dirigida pelo Papa. $<$ http://www.ecclesia.com.br/ biblioteca/historia_da_igreja/debates_sobre_a_natureza_do_cristo.html $>$ Acesso 04/03/2014. 
Terceira, o problema mais espinhoso, aquele de oferecer uma 'exegese' para um texto de difícil compreensão literal, cercado de 'desconfiança' por parte da inteligência ortodoxa grega, e por isso, Ecumênio não gozaria de uma larga tradição de comentários que o favorecessem nesta árdua tarefa.

\section{$1^{\text {a)}) \text { A Unidade Joânica }}{ }^{61}$}

Um elemento que interessa destacar é a unidade dos escritos joânicos, através da afirmação contundente do autor deste comentário, que o Apocalipse é um texto canônico, e portanto, inspirado e mais ainda, em linha com outros escritos do Novo Testamento. Ele estabelece um ‘diálogo' entre o Apocalipse e o Evangelho de João, reforçando a identidade da tradição do Apóstolo João.

Apesar da distância cronológica de alguns séculos, através da análise de Ap 10,11, sobre a profecia continuada, Ecumênio 'encena' um diálogo crítico $^{62}$ com as posições de Deonísio, destacam-se as respostas às aporias das diferenças entre o Evangelho e o Apocalipse.

${ }^{61}$ Outro elemento, a escatologia. Neste campo estamos diante de um dos mais contraditórios temas ao interno do "Corpo Joanino". Uma possível harmonização para o problema se encontra por exemplo nas opções exegéticas de R.Bultmann, que elimina trechos do IV Evangelho, com uma prospectiva escatológica futura, logicamente entendida como elemento redacional. Ou ainda segundo a opção de $J .-W$ Taeger, que aplica à mesma «escola joanina» os diversos estágios escatológicos, presente e futuro, supondo entre eles uma relação de interdependência e desenvolvimento. De um lado, justifica-se muito mais coerente ler a escatologia do Apocalipse como escatologia realizada, isto é no presente, através de um uso dialético particular ao grego do Apocalipse, excluindo evidentemente as correções redacionais do último editor. Por outro, poder-se-ia colocar ao lado do aspecto futuro da maioria das mensagens, o não irrelevante acento sobre o presente, próprio da realização salvífica. Isto sigifica que a partir da caracterização do Apocalipse nós teríamos uma escatologia realizada (Apoc 5,6ss//Jo 16,33) na plenificação da Cruz, como no $\mathrm{IV}^{\circ}$ Evangelho, na concentração escatológica representada pela "hora" de Jesus, evidentemente em outro campo linguístico. Um paralelo concreto surge em Apocalipse 12//Jo 12, 31. $\mathrm{O}$ aspecto atualizador da Presença de Cristo na sua comunidade é o Espírito. O aspecto presente é profundamente cristológico e vem sentido na experiência da Comunidade através do Espírito. FREY, J. "Erwägungen der Johannesapokalypse zu übrigens Schriften des Corpus Johanneum". In: HENGEL, M. Die Johanneische Frage. Berlin: WUNT 67, 1993, pp. 326-429. Cf. nota 4.

${ }^{62}$ A mesma estratégia utilizada por Orígenes em seu 'debate' com Celso, morto setenta anos antes. A realocação de um velho problema em um novo contexto, pode permitir o deslocamento de algumas tradições. No caso de Ecumênio, a tradição milenarista de leitura do Apocalipse: DOS SANTOS, P. P. “O Discurso da Verdade” (alethés Lógos) em 'Contra Celso' (Orígenes). Um Debate 'Filosófico(-teológico)' Judaico-cristão no Império Romano do III ${ }^{\circ}$ sec. d.C”. In: DA SILVA, A. C. e DE LIMA, F. L. A linha e corte: tensões e transformações na antiguidade clássica e na cultura oriental. Rio de Janeiro: Metáfora, 2013, pp. 292-312. 
Caracteriza a análise de Ecumênio a refutação à análise literalista, comum aos milenaristas e sectários, pois desfruta o texto através de uma 'poética do terror' e da catástrofe.

A atividade literária de Ecumênio centra-se em sua atividade de teólogo e bispo, isto é, defensor da fé 'ortodoxa', por isso, temas como a Trindade ${ }^{63}$, a natureza de Cristo, entre outros, orientam sua pesquisa exegética do 'corpus johanneum', fulcro de sua argumentação sobre a autenticidade do Apocalipse. Em campo da unidade dos escritos atribuídos à tradição joânica, o tema 'Anticristo', por exemplo, serve para tirar algumas conclusões em relação à datação do Apocalipse em relação às Cartas.

É clara a diferença de tratamento linguístico e teológico entre a Carta e o Apocalipse em relação à figura, à ação e ao significado teológico do Anticristo.

O modelo joânico do Anticristo na $1^{\text {a }}$ Carta Jo está profundamente relacionado à questão comunitária, lida à luz de uma visão escatológica, por causa da joânica terminologia da "última hora" ${ }^{64}$.

Porém, se é verdade que o tema venha tratado no Apocalipse em chave política: "konnte man auch an eine politische Herrschergestalt (...)" ${ }^{65} \mathrm{o}$ fundo cristão-primitivo (Mc 13, 14; 2Tes 2, 3ss) baseado na leitura apocalíptica judaica de Daniel, lê estes fatos à luz do tema dos inimigos de Deus.

O tema, por isso, possibilita uma conexão de fundo entre as Cartas e o Apocalipse a partir da crise comunitária, que trazem os sinais da aproximação do Anticristo.

A relação entre estes escritos, tendo como base a temática do Anticristo, seria de grande auxílio na reconstrução da datação do Apocalipse e ao mesmo tempo, da relação entre Evangelho e Cartas, isto é, com o conjunto dos Escritos da Tradição Joânica.

\footnotetext{
${ }^{63}$ SANTOS, P. P. A. "Jo 15,26: Cristo envia-nos do Pai o Espírito da Verdade: Dimensão Trinitária no Evangelho de João". Communio 82 (2000), pp. 89-101.

${ }^{64}$ JENKS, G.C. "The Origins and Early Development of the Antichrist Myth". BZNW 59 (1990), pp. 345-347.

${ }^{65}$ FREY, J. Erwägungen der Johannesapokalypse zu übrigens Schriften des Corpus Johanneum. In: HENGEL, M. Die Johanneische Frage. Berlin: WUNT 67, 1993, p 410.
} 
Um exemplo da exegese 'teológica' de Ecumênio é sua postura 'antinestoriana' ${ }^{66}$ evidenciada em sua 'mariologia', ao sustentar que o livro do Apocalipse está em linha com o título 'Theotókos' (Ap 1, 13). Sua argumentação é a seguinte, Ele é o Filho do Homem, porque recebeu a carne de Maria (nossa Irmã). Percebe-se aqui um diálogo com a tradição de Cirilo de Alexandria ${ }^{67}$

Levantam-se assim alguns aspectos como característicos da exegese Ecumênia no Apocalipse:

a) A Encarnação é obra da Trindade e de Maria, o que justifica seu título: A Theotókos;

b) Com 'alma racional', Cristo é constituída pela união completa e perfeita entre a Natureza do Verbo e a natureza humana de Maria;

c) A Encarnação aparece como uma apropriação da carne e por isso, como participação no sangue e na carne, não com a hipóstase de um homem, isto o coloca de fato na esfera da teologia Alexandrina;

d) Ele exclui explicitamente qualquer espécie de mudança no processo da Encarnação: O Verbo não perdeu nada no esvaziamento, nem ganhou nada ao encarnar-se.

A proximidade com as questões Cirilianas do monofisismo ou do neocalcedonismo na linguagem de Ecumênio não nos permite, segundo a Castagno enquadrá-lo simplesmente neste universo, como sectário de um movimento:

Individuar a posição teológica de Ecumênio é portanto, um problema mais complexo de quanto possa parecer em um primeiro momento; de outra parte, Ter jogado luz sobre o que há em comum em sua cristologia com o monofisismo e o neocalcedonismo torna imparcial a questão se ele pode ser considerado ou não como pertencente à primeira ou à segunda corrente teológica. É necessário, portanto, concentrar atenção sobre alguns elementos que não são compartilháveis entre ambas a correntes ${ }^{68}$.

${ }^{66}$ SIMONETTI, M. "Nestório e Nestorianismo". In: Dicionário Patrístico e de Antiguidades Cristãs. Petrópolis/São Paulo: Vozes/Paulus, 2002, pp. 995-997.

${ }^{67}$ SIMONETTI, M. "Cirilo de Alexandria”. In: Dicionário Patrístico e de Antiguidades Cristãs. Petrópolis/São Paulo: Vozes/Paulus, 2002, pp. 296-297. Sobre a 'mariologia' na Tradição joânica: SERRA, A. Le Nozze di Cana. Incidenze cristologico-mariane del primi 'segno' di Gesù. Padova: Messaggero di Padova, 2009.

${ }^{68}$ CASTAGNO, A. M. "I Commenti di Ecumenio, p. 322-323: 'Individuare la posizione teologica di Ecumenio è dunque un problema più complesso di quanto si possa sembrare in un primo momento; d'altro canto. L'aver messo in luce ciò che la sua Cristologia hà in 
Esta questão da natureza de Jesus no Comentário de Ecumênio levou alguns autores a enquadrá-lo no monofisismo ou no monotelismo mas, a leitura de seu comentário em pleno século $\mathrm{VI}^{\circ}$, contradiz esta possibilidade, haja vista a sua postura em relação ao Imperador.

\section{$\left.3^{a}\right)$ Método exegético}

Como já foi dito desde o início, a insistência de Ecumênio em sublinhar o acordo do Apocalipse com outros escritos de João e com o resto da Escritura (item 1), assim como, ao acentuar a pureza da teologia presente no livro apocalíptico (item 2), não foi senão um dos aspectos de seu esforço de promover a aceitação plena da dignidade Apostólica do livro do Apocalipse.

O problema mais sinuoso, porém, era aquele de realizar uma verdadeira 'decodificação' da linguagem apocalíptica ('mystikótatos'), que permanecia intransponível à maioria, dando lugar, seja a interpretações erradas, seja à marginalização deste texto por parte de exegetas 'prudentes'.

Quanto ainda mais difícil, como já afirmara Allo em 1921, pela ausência de uma sólida tradição exegética grega consolidada, mas somente fragmentárias citações, que sustentasse a operação hermenêutica de Ecumênio.

Em primeiro lugar Ecumênio utiliza o método alegórico, mas percebe-se pelo uso dos termos ' $\Theta \epsilon \omega \rho\left\llcorner\alpha{ }^{\prime 69} \mathrm{e}\right.$ 'óm $\tau \alpha \alpha \sigma^{\prime} \alpha^{\prime}{ }^{70}$, respectivamente, visão e espetáculo $^{71}$. Tudo isso para indicar que se trata de uma especificidade exegética do Livro do Apocalipse: alegórico deve ser entendido aqui como uma linguagem adequada à explicação de imagens e símbolos.

comune com il monofisismo Ed il neocalcedonismo, lascia impregiudicata la questione se egli possa considerarsi appartenenti alla prima o alla seconda corrente teológica. Bisogna quindi concentrare l'attenzione su quegli elementi che non sono condivisi da entrambe correnti'.

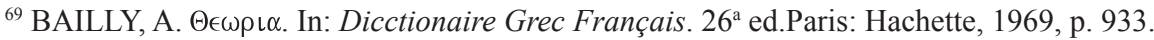

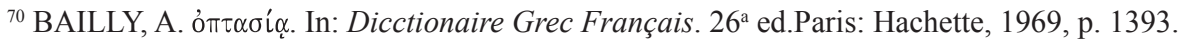

${ }^{71} \mathrm{O}$ verbo em grego não significa dentro do universo linguístico joanino, um simples ver, ao contrário, esse vem utilizado em um sentido muito preciso. Segundo a etimologia do verbo, este significa olhar um espetáculo, observar com atenção e concentração, em sentido figurado contemplar. O acento recai evidentemente sobre o aspecto ativo da ação. BAUER, W. A GreekEnglish Lexicon of the New Testament and Other Early Christian Literature by W.F. Arndt

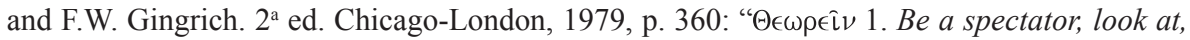
observe, perceive, see (w.physical eyes). 2. of perception by mind or spirit - a. notice, perceive, observe... b. of the spiritual perception of the one sent by God..."; mais detalhes, LIDELL, H. G. and SCOTT, R. A Greek-English Lexicon. 9a ed. Oxford, 1992, pp. 796-770, sobre o uso Patrístico, não se encontra o uso profano de ser espectador (espetáculo), LAMPE, G.W. $A$ Patristic Greek Lexicon. 9a ed. Oxford, 1989, p. 647. 
Por isso ele opera uma inversão metodológica: do símbolo à história (relações entre arcano e história). O Apocalipse constituía um desafio para o exegeta, pois, se todo texto era reconhecido por seus significados literais e históricos, e segundo as diversas escolas que já analisamos, apresentava um significado moral e espiritual, neste caso, não se tratava de encontrar uma história, mas, ultrapassando a linguagem simbólica delinear os nexos históricos que emergem da análise dos símbolos.

Um traço evidente da metodologia de Ecumênio diante do desafio de leitura simbólica da floresta de símbolos do Apocalipse é baseado no princípio da autoridade, como fica evidente em sua análise de Apoc 11,3.

O esforço exegético de Ecumênio, que dá lugar muitas vezes a virtuosismos interpretativos muito fantasiosos. Não se resolve em uma sucessão de tropos, simplesmente justapostos uns aos outros, mas é comandado por

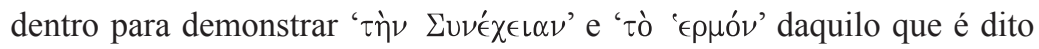
pelo livro de João e de perceber o fio condutor que o percorre do início ao fim, reconstruir através da decifração dos símbolos, os nexos lógicos e temporais, que parecem ausentes no próprio texto $(. . .)^{72}$.

Segunda a autora, uma exegese que desenha através da decifração do sistema simbólico os nexos lógicos, uma gramática simbólica do significado!

\section{Conclusão}

Quando um ensinamento, com efeito, leva esta forma alegórica, cada um é levado para em interpretar seguindo suas preocupações pessoais, ou ideias que tomaram curso até então no seu meio. O Apocalipse é escrito apaixonante, que devia superexcitar os espíritos dados à exaltação; a imaginação dos comentadores, sem nenhuma explicação oficial para orientá-los, dão curso livremente ao longo dos anos através dos séculos, desde os milenaristas até aos sectários iluminados de nossos dias (...). ${ }^{73}$

\footnotetext{
${ }^{72}$ CASTAGNO, A. M. "I Commenti di Ecumenio, p. 330: 'Lo sforzo exegetico di Ecumenio, che dà luogo talvolta a virtuosissimi interpretativi molto fantasiosi, non si risolve in uma successione di tropi, semplecimente giustapposti gli uni agli altri, ma è comandato dall'interno

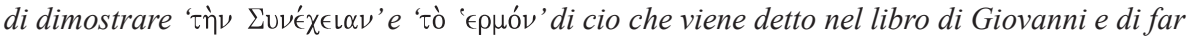
intravvedere il filo rosso che lo percorre dall'inizio alla fine, ricostruire atraverso la decifrazione dei simboli i nessi logici-temporali che appaiono assenti nel texto próprio (...)'.

${ }^{73}$ ALLO, E.-B. Saint Jean, p. CCXII: 'Quand un enseignement, em effet, revêt cette forme allegorique,chacun est porté à en entrepréter les details suivants ses préoccupations personnelles,
} 
No início do século passado, Allo traçou um breve roteiro daquilo que ele chamaria de 'systèmes d'explications' do estado caótico da história da interpretação do livro do Apocalipse na antiguidade.

Ele aponta o fato, que foi destacado anteriormente, na exposição dos Comentaristas, que, apesar das relações estabelecidas entre eles, seja pelo debate doutrinal e político, seja pelas afinidades ou conflitos exegéticos (escolas diversas), não havia à disposição destes intérpretes do Apocalipse uma cartilha de orientação 'oficial', vinda do autor ou do Magistério.

Assim, o desenvolvimento da 'imaginação" ${ }^{74}$ se coloca como uma parceira indispensável para entender como se estrutura e até se solidifica uma extensa tradição de leitura de textos apocalípticos no Ocidente.

Allo, então, baseado nesta premissa aponta ao menos três sistemas explicativos, que se apresentam como 'divergentes e marcados pelo subjetivismo' ('divergents et mèles de subjectivisme').

Mais ainda, para ele, neste estado de coisas é difícil isolar os elementos de uma verdadeira tradição hermenêutica, senão que o status quo da interpretação do Apocalipse mais parece um conjunto desconexo entre seus membros: "veritable "tradition" explicative. Elle existe pourtant, mais à l'état de "disjecta membra"75.

No primeiro sistema apresentado por Allo, a premissa é a constatação que o livro do Apocalipse não constitui uma 'novidade' literária, o gênero já existia no universo judaico, sendo considerado com estima pela Igreja. Alem do Profeta Daniel, muitos cristãos lidavam com diversos apócrifos como a “Assunção de Moisés", o "Livro de Henoque", entre outros ${ }^{76}$.

ou les idées qui ont eu cours jusque-là dans le millieu. L'Apocalypse est un écrit passionnant, qui devait surexcité les esprits portés à l'exaltation; l'imagination des commentateurs, qu'aucune explication officielle n'était là pour guider, s'est donc donne assez librement carrière au cours des âges, depuis les millénaristes jusqu'aux sectaires illuminés de nos jours (...)'.

$74 \mathrm{O}$ imaginário, segundo Iser, não é de natureza semântica; pois, ao contrário do sentido, que é preciso, ele tem um caráter difuso, este elemento é que caracteriza, no entanto, a sua aptidão para assumir configurações diversas. Neste sentido, o ambiente ficcional está aliado àquele do imaginário, por diversas razões. Iser qualifica as formas do conceito de ficção em três diferentes modos, nos quais a ficção é a configuração apta para o imaginário, ela não só organiza o imaginário, mas também organiza formas pragmáticas correspondentes. Nesta primeira perspectiva, a ficção aplica-se às relações do imaginário com o real: 'a configuração que o imaginário ganha pela ficção não conduz à modalidade do real que, através do uso do imaginário deve ser justamente revelado' (ISER, 2002, p. 948).

${ }^{75}$ ALLO, E.-B. Saint Jean, p. CCXII.

${ }^{76}$ DOS SANTOS, P. P. A. O Apocalipse Cristão e os Rolos de Qumran. Literatura e Movimentos 
Como a primeira citação do Apocalipse, como o conhecemos, ocorrerá somente sessenta anos depois com Justino ${ }^{77}$, era natural que este texto fosse lido no calor das questões e da ideologia majoritária naquele momento do Cristianismo antigo, isto é, as correntes escatológicas populares. Neste contexto, as leituras de Dan 7 e 11, aplicadas ao fim dos tempos, passam a ser o horizonte para interpretar as passagens do Apocalipse.

E isto não ocorre somente com a heresia de Cerinto, mas também com Papias, milenarista citado por Eusébio ${ }^{78}$. Mais tarde, S. Hipólito escreveu sobre o 'Anticristo'79, e como parece, inspirou-se para interpretar as páginas mais obscuras do Apocalipse na leitura milenarista de Daniel, como também em fontes extracanônicas circulantes em ambiente judaico-cristã dos primeiros séculos.

No segundo sistema, Allo refere-se ao fato que o Apocalipse tendo sido destinado aos seus contemporâneos, contém naturalmente certo número de traços ou alusões relativas à história da época (Imperador Domiciano?), à Roma, às perseguições recentes ou atuais, independentemente da profecia espiritual e universal.

Parece que as gerações cristãs, representadas por Justino e Hipólito, buscaram entender, no tempo presente da Igreja em que viviam, o cumprimento das profecias joânicas do Apocalipse, deixando para o futuro somente a vinda do Anticristo e a Consumação.

No último sistema, reação aos anteriores, os comentadores leram as 'profecias' apocalípticas de João como meras alegorias morais, com a impossibilidade, na maior parte, de se realizarem no tempo, mesmo que futuro. Isto

apocalípticos no Mundo Antigo e suas relações com Projetos Contemporâneos. Communio (2004), pp. 133-156.

${ }^{77}$ No Diálogo com Trifão, 81, ele alude ao Milenarismo e o atribui a João. DE SIMONE, R. J. “Justino, Filósofo e Mártir". In: Dicionário Patrístico e de Antiguidades Cristãs. Petrópolis/São Paulo: Vozes/Paulus, 2002, pp. 798-800; REVENTLOW, H. G. "La prima apologetica: Giustino Martire". In: . Storia dell'Interpretazione biblica. 1. vol. Casale Monferrato: Piemme, 1999, pp. 180-195; SIMONETTI, M. "Giustino". In: La Letteratura Cristiana Antica. .1 vol. Casale Monferrato: Piemme, 1996, pp. 212-247. Uma pesquisa mais extensa sobre as relações dos cristãos do $\mathrm{I}^{\circ}$ e II $^{\circ}$ séculos com a realidade (mundo): MINNERATH, R. "Les Chrétiens et Le Monde ( ${ }^{\mathrm{I} r}$ et II ${ }^{\mathrm{e}}$ Siécles)". Paris: Gabalda, 1973. Sobre esta obra aconselho meu artigo: DOS SANTOS, P. P. "Cristianismo e Gnosticismo: A recepção de elementos do Helenismo Religioso”. Principia XXVI (2013) pp. 15-30.

${ }^{78}$ EUSB. H. E. III, XXXIX, 11-12.

${ }^{79}$ TREVIJANO, R. “Anticristo”. In: Dicionário Patrístico e de Antiguidades Cristãs. Petrópolis/ São Paulo: Vozes/Paulus, 2002, p. 108. 
é, o texto perde seu jogo fictício sobre o tempo, aplicando-se à 'alma' do leitor, no seu presente espiritual ou moral.

Allo conclui, como havia acenado no início da sua formulação esquemática das redes interpretativas do Apocalipse, que o conjunto disléxico da interpretação exegético-teológica apocalíptica levou à percepção de divergências irredutíveis, que separam em duas partes, às vezes, irreconciliáveis, os atores deste cenário hermenêutico: Um verdadeiro 'emaranhado' de visões.

Estas diversas tendências, por vezes combinados em um emaranhado inextricável, explicam as discrepâncias irredutíveis que separaram os mais veneráveis intérpretes na Igreja Católica e as fantasias preferidas que acumulam a mente dos comentários dos Heterodoxos ${ }^{80}$.

Faltam ainda mais trabalhos sobre o estabelecimento de tradições interpretativas apocalípticas em debate, com seus interesses, impasses e idiossincrasias, que de certa maneira, estabelecem o modo de ler um livro como o Apocalipse, sobretudo, nestes tempos tão propícios aos extremos ${ }^{81}$.

\section{Referências Bibliográficas}

ALAND, B. "Die Rezeption des neutestamentlichen Textes in den ersten Jahrhunderten". In: SEVRIN, J.-M. The New Testament in Early Christianity. Louvain: Brill, 1989, pp. 1-38.

. "Montano - Montanismo". Dicionário Patrístico e de Antiguidades Cristãs. Petrópolis/São Paulo: Vozes/Paulus, 2002, pp. 959-961.

ALLO, E.-B. Saint Jean. L'Apocalypse. Paris: Gabalda, 1921.

ANDREI, O. "Dal De Antichristo di Ippolito al De Consummatione mundi del PsIppolito: "riscrivere" um texto e "comunicare storia". Studia Ephemeridis Augustinianum 90 (2004), pp. 89-119.

\footnotetext{
${ }^{80}$ ALLO, E.-B. Saint Jean, p. CCXVIII: 'Ce diverse tendences, parfois combinées dans une enchevêtrement inextricable, expliquent les divergences irréductibles que ont separé les plus venerables interprètes dans l'Église catholique, et les fantasies échevelées qui remplisent maint commentaires des hétérodoxes'.

${ }^{81}$ Indispensável, entre muitas outras, a leitura de DELUMEAU, J. A história do medo no ocidente 1300-1800. Uma cidade sitiada. São Paulo: Cia. das Letras, 2009.
} 
AUNE, D. E. Revelation 6-16. Nashville: Thomas Nelson, 1998.

BORRESEN, K. C. Gender and Exegesis in Latin Fathers. Patristicum 40 (2000), pp. 65-76.

BRUCE, F. F. The History of New Testament Study.New York: Doubleday, 1969.

CALTABIANO, M. Litterarum Lumem. Ambienti culturali e libri trai l IV e Vi secolo. Roma: Patristicum, 1996.

CASTAGNO, A. M. "I Commenti di Ecumenio e di Andrea di Cesarea: Due letture Divergenti dell'Apocalisse". Memorie dell'Accademia delle Scienze di Torino. Serie V. vol. 5, 1981, pp. 306-426.

CATAUDELLA, Q. "I cristiani e l'oltretomba pagano", Augustinianum 18/1 (1978), pp.7-28.

CZESZ, B. "La "tradizione" profética nella controvérsia montanista". Augustinianum (1989), pp. 55-70.

DOGLIO, C. Duemila anni di tentativi! Storia dell'interpretazione dell'Apocalisse. In: Parole di vita 45/6 (2000) pp. 4-12.

. Il Primogenito dei Morti. La Risurrezione di Cristo e dei cristiani nell'Apocalisse di Giovanni. Bologna: Dehoniane, 2005.

DOS SANTOS, P.P. “Os Manuscritos de Qumran e o Novo Testamento: Observações Preliminares e a Questão do Corpus Johanneum". Atualidade Teológica (1999), pp. 9-49.

. "A Profecia Cristã no Novo Testamento: Uma Tentativa de Reconstrução do fenômeno da Profecia no Cristianismo Primitivo". Atualidade Teológica (2000), pp. 71-102.

"Verdade e Espírito no âmbito da Teologia do Novo Testamento". Communio (2000), pp. 173-199.

. "O Apocalipse de Jesus Cristo. Testemunho e Espírito da Profecia. A Tradição e a Eclesialidade joaninas como fonte e testemunho na busca de Traços do Cristianismo Primitivo". Atualidade Teológica (2001) pp. 39-51. 
"O Apocalipse Cristão e os Rolos de Qumran. Literatura e Movimentos apocalípticos no Mundo Antigo e suas relações com Projetos Contemporâneos". Communio (2004), pp. 133-156.

Teológica (2008), pp. 29-41.

"Breve Percurso da Hermenêutica Bíblica". Atualidade

"O Contexto Religioso do Cristianismo Antigo e Gnosticismo: Identidade e âmbito da Mentalidade Helênica na Literatura Judaico-cristã tardoantiga. Um estudo sobre a obra de Hans-Josef Klaus (2000)". Revista Jesus Histórico (2010), pp. 1-9.

“O 'Movimento Joanino' e o Papel do "Espírito da Verdade" na Compreensão de Ap 19,9-10”. Atualidade Teológica (2010), pp. 77-100.

"As Fontes Literárias do termo "tó pneûma tés prophetéias” (Ap 19,10)”. Atualidade Teológica (2011), pp. 475-490.

"Stagnus Ignis: O Apocalipse reescreve Homero! Horizontes homéricos na Narração religiosa e mítica de Textos e Contextos Apocalípticos (Ap 20, 14-15)?”. Caderno Seminal Digital, (2012), pp. 113-123.

. "O Discurso da Verdade" (alethés Lógos) em 'Contra

Celso' (Orígenes). Um Debate 'Filosófico (-teológico)' Judaico-cristão no Império Romano do III ${ }^{\circ}$ sec. d.C. In: DA SILVA, A. C. e DE LIMA, F. L. A linha e corte: tensões e transformações na antiguidade clássica e na cultura oriental. Rio de Janeiro: Metáfora, 2013, pp. 292-312.

EMMERSON, E. K. e MCGINN, B. (Ed). The Apocalypse in the Middle Ages. New York: Cornell, 1993.

FILORAMO, G. "Rivelazione ed Escatologia nello Gnosticismo Cristiano del II secolo". Augustinianum 18/1 (1978), pp. 75-88.

FORD, J. M. "L'Anticristo e la Nuova Gerusalemme negli Scritti di Gioacchino dei Fiore". In: COLACRAI, E. B. Percorsi nell'Apocalisse di Giovani. Assisi: Cittadella, 2005, pp. 735-752.

GRYSON, R. 'Les Commenatires Patristiques Latins de L'Apocalypse'. Revue Théologique de Louvain 28 (1997), pp. 484-502. 
HARL, M. Le Déchiffrement du Sens. Études sur l'Hermenutique chrétienne d"Origène à Gregorie de Nyse. Paris: Cerf, 1983.

HARRISVILLE AND SUNDBERG. "Two Traditions of Historical Criticism". In: _. The Bible in Modern Culture. Theology and Historical-Critical Method from Spinoza to Käsemann. Michigan: Eardmans, 1995, pp. 262-273.

HELHOLM, D. Text and Context: Biblical Text in their textual and situational Context. Olson-Boston, 1995.

IRMSCHER, J. 'La Valutazione dell'Apocalisse nella Chiesa Antica'. Augustinianum, (1989), pp. 171-176.

JIMÉNEZ, F. M. F. El Comentario sobre el Apocalipsis" de Ecumenio en la controversia cristológica del siglo VI en Bizancio. Madrid: San Damazo, 2013.

L'Apocalypse expliquée para Cesaire D'Arles. DDB, Paris: Bouwer, 1989.

L'Esegesi dei Padri Latini. Roma: Patristicum, 2000.

KLIJN, A. F. J. “Cerinto e cerintianos". Dicionário Patrístico e de Antiguidades Cristãs. Petrópolis/São Paulo: Vozes/Paulus, 2002, pp 285.

MARAFIOTI, D. "Il Contesto del "Civitate Dei" di Sant'Agostino". In: CASAlEGNO, A. Tempo Ed eternità. In Dialogo com Ugo Vanni sj, Torino: San Paolo, 2002, pp. 217-234.

MARUCCI, C. "La Canocicità dell'Apocalisse nel Primo Milennio". In: COLACRAI, E. B. Percorsi nell'Apocalisse di Giovani. Assisi: Cittadella, 2005, pp. 649-676.

MAZZUCCO, C. e PIETRELLA, E. "La Concezione del Millennio e L'Apocalisse di Giovanni”. Augustinianum 18/1 (1978), pp. 29-45.

MONACI, A. "Apocalisse ed Escatologia in Origene”. Augustinianum 18/1 (1978), pp. 139-151.

MORETTI, P. F. "L'Esegesi biblica dei Padri: un generi letterario?" In: CONSOLINO, F. C (cura). Forme Litterarie nella Produzione Latina di IV-V secolo. Roma: Herder, 2003, pp. 129-146. 
ORECCHIA, C. "Univocità e Polissemia del texto bíblico nella Storia dell'interpretazione". In: ANGELINI, G (Cura). La Rivelazione Attestata. La Bibbia fra Texto e Teologia. Milano: Glosa, 1998, pp. 99-132.

PANNI, G. "L'Anticristo nel Commento all'Apocalisse di Vittorino di Petovio". In: COLACRAI, E. B. Percorsi nell'Apocalisse di Giovani. Assisi: Cittadella, 2005, pp.677-702.

POLLASTRI, A. "L'Apocalisse nell'Ambrosiaster: Una Lettura Millenarista nella Roma del IV secolo?" In: COLACRAI, E. B.Percorsinell'Apocalisse di Giovani. Assisi: Cittadella, 2005, pp. 703-734.

REVENTLOW, H. G. Storia dell'Interpretazione biblica. 3 vol. Casale Monferrato: Piemme, 1999.

ROLOFF, J. Die Kirche im Neuen Testament. Göttingen: Vandenhoeck \&Ruprecht, 1993.

ROMERO-POSE, E. "Los Ángeles de las Iglesias (Exegesis de Ticonio al Apoc. I, 20,22)”. Augustinianum 35 (1995), pp. 119-136.

. "Apocalipse/Apocalíptica". Dicionário Patrístico e de Antiguidades Cristãs. Petrópolis/São Paulo: Vozes/Paulus, 2002, pp. 126-128.

SEQUERI, P. "La Struttura testimoniale delle Scritture sacre: teologia del testo". In: ANGELINI, G. (org.) La Rivelazione Attestata. La Bibia fra Testo e Teologia. Milano: Glossa, 1998, pp. 3-28.

SIMONETTI, M. Lettera e/o Allegoria. Un Contributo Alla storia dell'esegesi patrística. Roma: Patristicum, 1985.

. La Letteratura Cristiana Antica. 3 vol. Casale Monferrato: Piemme, 1996.

.Sulla Teologia Trinitária di Origene, in Studi sulla Cristologia del II e III secolo", Studia Ephemeridis Augustianum 44 (1993), pp. 109-144.

"Monoenergismo - Monotelismo". Dicionário Patrístico e de Antiguidades Cristãs. Petrópolis/São Paulo: Vozes/Paulus, 2002, pp. 956. 
"Monofisitas". Dicionário Patrístico e de Antiguidades Cristãs. Petrópolis/São Paulo: Vozes/Paulus, 2002, pp. 956-959.

SONNET, J.-P. “La Bible et l'histoire, la Bible et son histoire: une responsabilité critique". Gregorianum 94/3 (2013), pp. 455-477.

TRISOGLIO, F. "Eusebio di Cesarea e l'Escatologia”. Augustinianum 18/1, Roma, 1978, pp. 173-182.

UBIERNA, P. "Recherches sur l'apocalyptique syriaque et byzantine auviiesiècle: la place de l'Empire romain dans une histoire du salut. Bulletin du centre d'études médiévales d'Auxerre" BUCEMA, Horssérie $\mathrm{n}^{\circ} 2$ (2008). Disponível em file://D:/meus\%20documentos/ Downloads/cem-10895-hors-serie-n-2-recherches-sur-1-apocalyptiquesyriaque-et-byzantine-au-viie-siecle-la-place-de-1-empire-romain-dansune-histoire-du-salut\%20(2).pdf Acesso em 24/02/2014.

VANNI, U. "Il tempo Ed Eternità nell'Apocalisse. Traccie per una riflessione Teologico-biblica". In: CASALEGNO, A. Tempo Ed eternità. In Dialogo com Ugo Vanni sj, Torino: San Paolo, 2002, pp. 25-72.

VANYÓ, L. "Pápias de Hierápolis". Dicionário Patrístico e de Antiguidades Cristãs. Petrópolis/São Paulo: Vozes/Paulus, 2002, p. 1087.

\section{Pedro Paulo Alves dos Santos}

Doutor em Teologia Bíblica - PUG - Roma (1997)

Doutor em Estudos Literários - PUC - Rio (2006)

Professor de Letras - Unicarioca

Rio de Janeiro/RJ - Brasil

E-mail: pedosantos@gmail.com

Recebido em: 15/03/14

Aprovado em: 06/05/14 